\title{
Determinants of undernutrition in rural communities of a protected area in Gabon
}

\author{
S Blaney ${ }^{1,2, *}, M$ Beaudry ${ }^{2}$ and $M$ Latham $^{3}$ \\ 'World Wide Fund for Nature, Bayanga, Central African Republic: ${ }^{2}$ Département des Sciences des Aliments et \\ de Nutrition (FSAA), Université Laval, Québec, Québec, Canada, G1K 7P4: ${ }^{3}$ Division of Nutritional Sciences, \\ Cornell University, Ithaca, NY, USA
}

Submitted 11 July 2007: Accepted 2 October 2008: First published online 9 December 2008

\begin{abstract}
Objective: To understand how access to natural resources may contribute to nutrition.

Design: In each of the two major seasons, data were collected during a $7 \mathrm{~d}$ period using observations, semi-structured interviews, anthropometric measures and a weighed food consumption survey.

Setting: Four rural communities selected to represent inland and coastal areas of the Gamba Complex in Gabon.

Subjects: In each community, all individuals from groups vulnerable to malnutrition, i.e. children aged $0-23$ months ( $n$ 41) and $24-59$ months ( $n$ 63) and the elderly ( $n$ 101), as well as women caregivers ( $n$ 96).

Results: In most groups, household access to natural resources was associated with household access to food but not with individual nutritional status. In children aged 0-23 months, access to care and to health services and a healthy environment were the best predictors of length-for-age (adjusted $R^{2}: 14 \%$ ). Health status was the only predictor of weight-for-height in children aged 24-59 months (adjusted $R^{2}: 14 \%$ ). In women caregivers, household food security was negatively associated with nutritional status, as was being younger than 20 years (adjusted $\left.R^{2}: 16 \%\right)$. Among the elderly, only nutrient adequacy predicted nutritional status (adjusted $R^{2}: 5 \%$ ).

Conclusion: Improving access to care and health for young children would help reverse the process of undernutrition. Reaching a better understanding of how the access of individuals to both food and other resources relate to household access could further our appreciation of the constraints to good nutrition. This is particularly relevant in women to ensure that their possibly important contribution to the household is not at their own expense.
\end{abstract}

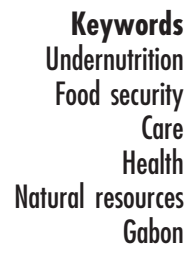

The degradation of ecosystems is a barrier to achieving the Millennium Development Goals, including those related to poverty and hunger ${ }^{(1)}$, in part because natural resources are important for household food security and for the security of household livelihoods ${ }^{(2)}$. Protected areas can play a role to preserve ecosystems, although they should do so without harming people ${ }^{(3)}$.

The Gamba Complex of Protected Areas in Gabon is inhabited by approximately 10000 persons spread out in thirty-three villages (2973 inhabitants) and one city (7226 inhabitants) ${ }^{(4)}$. If legislation prohibiting the extraction of natural resources ${ }^{(5)}$ were applied consistently, there is serious concern over the possibility of harmonizing the needs of people and the conservation of resources. This is particularly the case in rural areas where people rely on natural resources for their livelihood. We have previously shown that undernutrition was prevalent in the Complex, especially among the under- $5 \mathrm{~s}$ and the elderly ${ }^{(6)}$. Inadequate intakes of energy and $\mathrm{Fe}$ were frequent in most age groups. Illness during the survey was reported only for about $50 \%$ of children under 5 years of age, and much less for the majority of other respondents. Global nutrient adequacy was associated with nutritional outcome. To help determine the main constraints to better nutrition among this population, the present paper examines the relationship between nutritional status and household access to natural resources via its relationship to the immediate and underlying determinants of nutritional between nutritional status and its immediate and underlying determinants in the same study has not been done before. Our paper focuses on the most undernourished status $^{(7,8)}$. To our knowledge, assessing the relationship 
groups as well as on women because they are the main caregivers.

\section{Methodology}

\section{Sampling and data collection}

Details have been described elsewhere ${ }^{(6)}$. In summary, in each of the two major seasons, we requested the participation of all households in four rural communities of the Gamba Complex, non-randomly selected to represent the rural population. Several methods were used to collect data by the main author (MA) and a team of trained surveyors (TS): a weighed survey of the consumption of food and natural resources (TS), the weight and height/ length of individuals (MA), semi-structured interviews (MA) and observations (MA and TS). Over a one-week period, a $7 \mathrm{~d}$ weighed food consumption survey was carried out for all individuals ${ }^{(9)}$, individual health status was recorded daily as was household use of natural resources, the weight and height/length of each individual were measured once using recommended methods ${ }^{(10)}$ and data on access to care was collected for individuals in vulnerable groups.

In each household, two semi-structured interviews were conducted (MA): one with the household head and his wife and the second with the wife alone and with any caregiver of children under 5 years of age to collect data on: (i) sociodemographics including all income and its source as well as all expenses and their nature; (ii) care for women; (iii) health status of all household members over the last two months and health practices towards them; (iv) autonomy of women and their workload; and (v) hygiene practices towards children under 5 years and within the household. To assess the reliability of data, some information (e.g. health practices) was collected both from interviews and the health/pregnancy cards and the weight of young children was measured daily (MA). The following were also recorded daily, guided by an observation grid (MA and TS): (i) active complementary feeding of children under 2 years of age; (ii) hygiene practices towards children under 5 years; (iii) food preparation practices; (iv) household hygiene; (v) women's workload; (vi) presence and type of illness; (vii) use of bed nets by women and children; and (viii) ownership of assets. A latrine and a garbage pit were sought (MA). Distance of the pit from the house was measured with a tape ( $50 \mathrm{~m}$ accurate to $\pm 0 \cdot 01 \mathrm{~m}$ ). Because of participants' discomfort when questioned about a latrine, its remoteness from the house was estimated based on distance measured as just described.

At the village level, the source of drinking water and the presence of a health facility were recorded (in the latter, also the staffing and the availability of medicines), as was the market value of all resources used in the village (MA).

\section{Data analysis}

Food intake data were coded into the WorldFood Dietary Assessment software version $2 \cdot 0$ (University of California, Berkeley, CA, USA) for initial analysis and the results (per capita food and nutrient intake) transferred to the SPSS statistical software package version $13 \cdot 0$ (SPSS Inc., Chicago, IL, USA) for further analysis. Weight, height/length, birth date of young children and date of the measures were coded into the Anthro 2005 software version Beta (WHO, Geneva, Switzerland) for initial analysis and the resulting indices of height/length-for-age, weight-for-age and weight-for-height/length were transferred into SPSS for further analysis. All other data were coded directly into SPSS. Duplicate coding of a $10 \%$ random sample of data was carried out to ensure its reliability.

\section{Nutritional status}

Nutritional status in children under 5 years of age was assessed from height/length-for-age and weight-for-height/ length ${ }^{(10,11)}$ and in adults from $\mathrm{BMI}^{(10)}$. Children with a height/length-for-age or weight-for-height/length below $-1 \mathrm{sD}$ from the median value of the $2006 \mathrm{WHO}$ growth standards ${ }^{(12)}$ were considered undernourished. In adults, a BMI below $18 \cdot 5 \mathrm{~kg} / \mathrm{m}^{2}$ indicated underweight ${ }^{(10,13)}$.

\section{Nutrient adequacy and health status}

In each season, a global score of nutrient adequacy was calculated for each individual by adding his/her mean degree of fulfilment of requirements for energy, protein, Fe and vitamin A and dividing the total by 100 to obtain a score on 4 points ${ }^{(6)}$. The mean of both seasons for each individual became the measure of his/her usual degree of adequacy of nutrient intake.

In each season, a score of health status was attributed to each individual depending on whether or not he/she was ill during the days surveyed and on the nature and duration of illness ${ }^{(6)}$. The mean of both seasons was then calculated. The maximum score was $10 \cdot 5$ (not sick).

\section{Access to food (food security)}

'Food security exists when all people at all times, have physical and economic access to sufficient, safe and nutritious food to meet their dietary needs and food preferences for an active and healthy life, ${ }^{,(14)}$. Although other definitions of food security have been proposed, almost all include four key dimensions: access, security, sufficiency and time ${ }^{(15)}$. Food can be available but not accessible when people's entitlements to food are eroded ${ }^{(16)}$. Entitlements refer to the set of income and resource bundles over which households can establish control to secure their livelihood and food security $^{(16)}$. In the Complex, food entitlements are derived through production, trade, sale of labour and from transfers. Households have free access to state land and they own the minimum of assets required to produce food. Bushmeat is almost the only resource for which access is restricted. Some households rear a few animals and most do not keep food 
over many days. Gifts of food are common. The security dimension of a household's food security builds on its vulnerability to the failure of entitlements ${ }^{(15)}$. A household's risk profile depends on the channels through which access to food is normally mediated and on the assets it can rely on as buffers. When they are limited, a greater share of income may be used to obtain food. Thus, the most food-insecure households are likely to be those using a larger proportion of available resources (e.g. income) to secure food ${ }^{(17,18)}$. Having sufficient food is necessary to achieve a healthy and active life. Food therefore needs to meet more than energy requirements. Sufficient food must also be accessible at all times. Although staple foods, fish and meat are available year round in the Complex, the availability of vegetables is somewhat seasonal ${ }^{(19,20)}$.

In Africa, no standardized measure of household food security exists although the US Household Food Security Scale was recently tested ${ }^{(21)}$. Our field work pre-dated these tests. We therefore grounded our assessment on the model proposed by Jonsson and Toole ${ }^{(18)}$ and adapted by Maxwell et al. ${ }^{(17)}$. It classifies households into one of four categories based on the adequacy of their energy intake and the share of their income spent on food, thus considering the sufficiency and security dimensions of food security. To better reflect the quality of food and not only its quantity, we considered three additional nutrients. The measure was repeated in the two major seasons to consider the time dimension.

Based on the mean individual intake of each of the four nutrients over each $7 \mathrm{~d}$ period, a household score of available nutrient adequacy was derived by summing intakes for each nutrient for all members and dividing it by the sum of their requirements. In each season, four results representing the mean household adequacy in each of the four nutrients were thus obtained for each household. Each result represents the potential fulfilment of the requirements in each nutrient for each household member if both food and requirements were distributed equally among them.

The proportion of household weekly income dedicated to food and alcoholic beverages was estimated. Household access to food was initially estimated as follows for each season;

1. Food-secure: mean household adequacy for at least two of the four nutrients was $\geq 75 \%$ while $<50 \%$ of income was spent on food.

2. Vulnerable: mean adequacy for at least two of the four nutrients was $\geq 75 \%$ and $\geq 50 \%$ of income was spent on food.

3. Questionable: mean adequacy for at least two of the four nutrients was $<75 \%$ and $<50 \%$ of income was spent on food.

4. Food-insecure: mean adequacy for at least two of the four nutrients was $<75 \%$ and $\geq 50 \%$ of income was spent on food.

Given the distribution of households, this resulted in ten categories which were collapsed into four to attribute a final score of food security to each household (Table 1). Because individuals generally gain access to food through their household, each was assigned the score of his household to estimate his/her food security.

Access to care

Care has been defined as 'the provision in the household and the community, of time, attention and support to meet

Table 1 Index of household food security: criteria and population distribution

\begin{tabular}{|c|c|c|c|c|c|c|c|c|c|}
\hline \multirow{2}{*}{$\begin{array}{l}\text { Nutrient } \\
\text { adequacy* }\end{array}$} & \multirow{2}{*}{$\begin{array}{l}\text { Share of income } \\
\text { on food/alcohol }\end{array}$} & \multirow{2}{*}{$\begin{array}{l}\text { Seasonal } \\
\text { pattern }\end{array}$} & \multirow{2}{*}{$\begin{array}{l}\text { Initial } \\
\text { score }\end{array}$} & \multicolumn{2}{|c|}{$\begin{array}{l}\text { Distribution according } \\
\text { to initial score }\end{array}$} & \multirow{2}{*}{$\begin{array}{l}\text { Final } \\
\text { score }\end{array}$} & \multicolumn{2}{|c|}{$\begin{array}{l}\text { Distribution according } \\
\text { to final score }\end{array}$} & \multirow{2}{*}{$\begin{array}{l}\text { Degree of food } \\
\text { insecurity }\end{array}$} \\
\hline & & & & $n$ & $\%$ & & $n$ & $\%$ & \\
\hline$<75 \%$ & $\geq 50 \%$ & Both & 1 & 14 & 16 & 1 & 14 & 16 & Severe \\
\hline $\begin{array}{l}<75 \% \\
<75 \% \\
<75 \% \\
\geq 75 \%\end{array}$ & $\begin{array}{l}\geq 50 \% \\
<50 \% \\
\geq 50 \% \\
\geq 50 \%\end{array}$ & $\begin{array}{l}\text { One season } \\
\text { Other season } \\
\text { One season } \\
\text { Other season }\end{array}$ & $\begin{array}{l}2 \\
3\end{array}$ & $\begin{array}{r}18 \\
4\end{array}$ & $\begin{array}{r}20 \\
3\end{array}$ & 2 & 22 & 23 & Moderate \\
\hline $\begin{array}{l}<75 \% \\
<75 \% \\
\geq 75 \% \\
\geq 75 \% \\
<75 \% \\
\geq 75 \%\end{array}$ & $\begin{array}{l}<50 \% \\
<50 \% \\
\geq 50 \% \\
\geq 50 \% \\
\geq 50 \% \\
<50 \%\end{array}$ & $\begin{array}{l}\text { Both } \\
\text { One season } \\
\text { Other season } \\
\text { Both } \\
\text { One season } \\
\text { Other season }\end{array}$ & $\begin{array}{l}4 \\
5 \\
6 \\
6 \\
7\end{array}$ & $\begin{array}{r}15 \\
8 \\
\\
10 \\
7\end{array}$ & $\begin{array}{r}16 \\
8 \\
\\
10 \\
7\end{array}$ & 3 & 40 & 41 & Light \\
\hline $\begin{array}{l}<75 \% \\
\geq 75 \% \\
\geq 75 \% \\
\geq 75 \% \\
\geq 75 \%\end{array}$ & $\begin{array}{l}<50 \% \\
<50 \% \\
\geq 50 \% \\
<50 \% \\
<50 \%\end{array}$ & $\begin{array}{l}\text { One season } \\
\text { Other season } \\
\text { One season } \\
\text { Other season } \\
\text { Both }\end{array}$ & $\begin{array}{r}8 \\
9 \\
10\end{array}$ & $\begin{array}{r}12 \\
4 \\
3\end{array}$ & $\begin{array}{r}12 \\
4 \\
4\end{array}$ & 4 & 19 & 20 & Vulnerable/food-secure \\
\hline$N$ (households) & & & & 95 & 100 & & 95 & 100 & \\
\hline
\end{tabular}

*Adequacy of the household intake for at least two of four nutrients: energy, protein, vitamin A, Fe. 
the physical, emotional, intellectual and social needs of the growing child and of other family members ${ }^{,(22)}$. Its importance for the nutrition of young children is well documented $^{(23-26)}$, although that for the nutrition of women and especially of the elderly is less well understood, particularly in developing countries. Engle et al. ${ }^{(24)}$ proposed a framework to define the care needed by children under 3 years of age and also by women, since in most societies they are the caregivers. The care that women receive can impact not only their health or nutritional status, but also their ability to care for children.

Care practices towards children relate to breast-feeding and complementary feeding, food preparation and storage, hygiene and health practices, and psycho-social care ${ }^{(24)}$. For women, care practices can relate to pregnancy and lactation, reproductive health, workload and autonomy ${ }^{(24)}$. In Gabon, although there are some national-level data on care practices for young children and women ${ }^{(27)}$, there is no information on these practices in the Complex.

To assess care practices, we developed three indices derived from the framework of Engle et al. ${ }^{(24)}$ : for children under 5 years, for women caregivers and for the elderly (Tables 2-4). In each index, all constructs were given equal weight ${ }^{(28)}$. Data from both seasons were combined for the analysis.

Care for children. Because of the age-specific nature of recommendations on feeding practices for children, three sets of criteria were applied: (i) below 6 months of

Table 2 Index of access to care for children under 5 years old: criteria and population distribution

\begin{tabular}{|c|c|c|c|c|}
\hline Constructs and indicators & Criteria & Score & $n$ & $\%$ \\
\hline \multicolumn{5}{|l|}{ Feeding practices } \\
\hline \multicolumn{5}{|l|}{$<6$ months } \\
\hline \multirow{3}{*}{ Breast-feeding practice } & Not exclusive + artificial milk & 1 & 4 & 31 \\
\hline & Not exclusive + food/water & 2 & 7 & 54 \\
\hline & Exclusive & 4 & 2 & 15 \\
\hline \multirow[t]{2}{*}{ Breast-feeding frequency } & Low (1-3 times/d) & 1 & 2 & 15 \\
\hline & Average $(4-6$ times/d)/high ( $\geq 7$ times $/ \mathrm{d}$ ) & 2 & 11 & 85 \\
\hline \multirow{3}{*}{ Encouragements to breast-feed } & $\geq 1$ time $/ \mathrm{d}$ for $<10 \%$ of days surveyed & 0 & 6 & 46 \\
\hline & $\geq 1$ time $/ \mathrm{d}$ for $10-49 \%$ of days surveyed & 1 & 5 & 39 \\
\hline & $\geq 1$ time $/ \mathrm{d}$ for $\geq 50 \%$ of days surveyed & 2 & 2 & 15 \\
\hline \multicolumn{2}{|l|}{ Total } & $\begin{array}{l}8 \text { points (pts) } \\
\text { standardized (std) to } 5 \text { pts }\end{array}$ & 13 & 100 \\
\hline \multicolumn{5}{|l|}{$6-23$ months } \\
\hline \multirow[t]{2}{*}{ Breast-feeding } & No & 0 & 17 & 61 \\
\hline & Yes & 2 & 11 & 39 \\
\hline \multirow{2}{*}{$\begin{array}{l}\text { Adequate energy density of } \\
\text { complementary food }\end{array}$} & No & 0 & 4 & 14 \\
\hline & Yes & 1 & 24 & 86 \\
\hline \multirow[t]{2}{*}{ Adequate number of meals } & No & 0 & 17 & 61 \\
\hline & Yes & 1 & 11 & 39 \\
\hline \multirow{3}{*}{ Consumption of vitamin-A-rich foods } & None & 0 & 7 & 25 \\
\hline & $\geq 1$ time/d for $<50 \%$ of days surveyed & 1 & 14 & 50 \\
\hline & $\geq 1$ time $/ \mathrm{d}$ for $\geq 50 \%$ of days surveyed & 2 & 7 & 25 \\
\hline \multirow{3}{*}{$\begin{array}{l}\text { Consumption of meat/chicken/fish/ } \\
\text { legumest }\end{array}$} & None & 0 & 5 & 23 \\
\hline & $\geq 1$ time/d for $<50 \%$ of days surveyed & 1 & $13+t$ & 59 \\
\hline & $\geq 1$ time $/ \mathrm{d}$ for $\geq 50 \%$ of days surveyed & 2 & 4 & 18 \\
\hline \multirow[t]{3}{*}{ Help to eat at meals } & $\geq 1$ time/d for $<10 \%$ of days surveyed & 0 & 5 & 18 \\
\hline & $\geq 1$ time $/ \mathrm{d}$ for $10-49 \%$ of days surveyed & 1 & 6 & 21 \\
\hline & $\geq 1$ time $/ \mathrm{d}$ for $\geq 50 \%$ of days surveyed & 2 & 17 & 61 \\
\hline \multirow[t]{3}{*}{ Verbal encouragements to eat at meals } & $\geq 1$ time/d for $<10 \%$ of days surveyed & 0 & 7 & 25 \\
\hline & $\geq 1$ time $/ \mathrm{d}$ for $10-49 \%$ of days surveyed & 1 & 11 & 39 \\
\hline & $\geq 1$ time $/ \mathrm{d}$ for $\geq 50 \%$ of days surveyed & 2 & 10 & 36 \\
\hline Total & & $10 / 12 / 13$ pts (std to $5 \mathrm{pts}$ ) & 28 & 100 \\
\hline \multicolumn{5}{|l|}{ 24-59 months } \\
\hline \multirow[t]{3}{*}{ Quality of meals } & $\geq 50 \%$ of meals $=$ staple & 0 & 21 & 33 \\
\hline & $\geq 50 \%=$ staple + vitamin A-rich food & 1 & 6 & 9 \\
\hline & $\begin{array}{l}\geq 50 \%=\text { staple + meat/chicken/fish/ } \\
\text { legumes } \$\end{array}$ & 2 & 36 & 58 \\
\hline \multirow[t]{4}{*}{ Number of meals/d (at least staple) } & 1 & 0 & 2 & 3 \\
\hline & 2 & 1 & 16 & 25 \\
\hline & 3 & 2 & 40 & 64 \\
\hline & $\geq 4$ & 3 & 5 & 8 \\
\hline Total & & 5 pts & 63 & 100 \\
\hline \multicolumn{5}{|l|}{ Food preparation } \\
\hline \multicolumn{5}{|l|}{$\%$ of meals prepared } \\
\hline \multirow[t]{3}{*}{ Without animals around } & $0-49 \%$ & 0 & 34 & 33 \\
\hline & $50-74 \%$ & 1 & 22 & 21 \\
\hline & $\geq 75 \%$ & 2 & 48 & 46 \\
\hline
\end{tabular}


Table 2 Continued

\begin{tabular}{|c|c|c|c|c|}
\hline Constructs and indicators & Criteria & Score & $n$ & $\%$ \\
\hline \multirow[t]{3}{*}{ After washing hands } & $0-49 \%$ & 0 & 18 & 17 \\
\hline & $50-74 \%$ & 1 & 25 & 24 \\
\hline & $\geq 75 \%$ & 2 & 61 & 59 \\
\hline \multirow[t]{3}{*}{ Dishes washed with soap } & $0-49 \%$ & 0 & 3 & 3 \\
\hline & $50-74 \%$ & 1 & 13 & 13 \\
\hline & $\geq 75 \%$ & 2 & 88 & 84 \\
\hline Total & & 6 pts (std to 5 pts) & 104 & 100 \\
\hline \multicolumn{5}{|l|}{ Hygiene - household level } \\
\hline \multirow[t]{4}{*}{ Drinking water used } & Open water point, both seasons & 0 & 49 & 47 \\
\hline & $\begin{array}{l}\text { Rainwater in season 1; open water point in } \\
\text { season } 2\end{array}$ & 1 & 20 & 19 \\
\hline & Rainwater, both seasons & 2 & 32 & 31 \\
\hline & Water from pump, both seasons & 3 & 3 & 3 \\
\hline \multirow[t]{2}{*}{ Frequency of house cleaning } & $<1$ time/d & 0 & 44 & 42 \\
\hline & $\geq 1$ time/d & 1 & 60 & 58 \\
\hline Total & & 4 pts (std to 5 pts) & 104 & 100 \\
\hline \multicolumn{5}{|l|}{ Hygiene - child level } \\
\hline \multirow[t]{4}{*}{ Bathing $\geqslant 1$ time/d } & $<25 \%$ of days surveyed & 0 & 2 & 2 \\
\hline & $25-49 \%$ of days surveyed & 1 & 4 & 4 \\
\hline & $50-74 \%$ of days surveyed & 2 & 15 & 14 \\
\hline & $\geq 75 \%$ of days surveyed & 3 & 83 & 80 \\
\hline \multirow[t]{4}{*}{ Hand-washing before meals $\geq 1$ time/d } & $<25 \%$ of days surveyed & 0 & 44 & 42 \\
\hline & $25-49 \%$ of days surveyed & 1 & 10 & 10 \\
\hline & $50-74 \%$ of days surveyed & 2 & 14 & 13 \\
\hline & $\geq 75 \%$ of days surveyed & 3 & 36 & 35 \\
\hline \multirow[t]{4}{*}{ Disposal of child faeces } & (i) Anywhere, both seasons & 0 & 20 & 19 \\
\hline & (ii) Anywhere one season, (iii) in other & 1 & 9 & 9 \\
\hline & (iii) Ground, then latrine, both seasons & 2 & 64 & 61 \\
\hline & (iv) Pot, then latrine, both seasons & 3 & 11 & 11 \\
\hline Total & & 9 pts (std to 5 pts) & 104 & 100 \\
\hline \multicolumn{5}{|l|}{ Health } \\
\hline \multirow{2}{*}{\multicolumn{2}{|c|}{$\begin{array}{l}\text { Not sick, last two months } \\
\text { If sick }\end{array}$}} & $6 \cdot 5$ & 32 & 31 \\
\hline & & & 72 & 69 \\
\hline \multirow[t]{4}{*}{ Delay before consultation } & No consultation & 0 & 10 & 14 \\
\hline & $\geq 3 \mathrm{~d}$ & 0.5 & 6 & 8 \\
\hline & $1-2 d$ & 1 & 41 & 57 \\
\hline & Same day & $1 \cdot 5$ & 15 & 21 \\
\hline \multirow[t]{2}{*}{ Place of consultation } & House & 1 & 30 & 48 \\
\hline & Health facility & 2 & 32 & 52 \\
\hline \multirow[t]{2}{*}{ Type of treatment } & Traditional/modern & 1 & 56 & 90 \\
\hline & Both & 2 & 6 & 10 \\
\hline \multirow[t]{2}{*}{ Health personnel consulted } & No & 0 & 28 & 45 \\
\hline & Yes & 1 & 34 & 55 \\
\hline \multirow[t]{2}{*}{ Sleeps under bed net } & No & 0 & 25 & 24 \\
\hline & Yes & 1 & 79 & 76 \\
\hline \multirow[t]{4}{*}{ Adequacy of immunization } & None & 0 & 25 & 24 \\
\hline & Partial & 1 & 43 & 41 \\
\hline & Completell & 3 & 31 & 30 \\
\hline & No data & - & 5 & 5 \\
\hline Total & & $10.5 \mathrm{pts}$ (std to $5 \mathrm{pts}$ ) & 104 & 100 \\
\hline Care to the caregiver & (see Table 3) & 35 pts (std to 5 pts) & 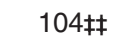 & 100 \\
\hline Maximum possible & & 30 pts (std to 4 pts) & 104 & 100 \\
\hline$N$ (children aged 0-59 months) & & & 104 & \\
\hline Mean score & & & $2 \cdot 32$ (SE & \\
\hline Range & & & $1 \cdot 16-3$ & \\
\hline
\end{tabular}

tConsumption of meat/chicken/fish/legumes was not assessed for children aged 6-8 months ( $n$ 6); their score was therefore calculated on a potential total of 10 pts.

fFor children aged $12-23$ months, criteria and scores were as follows: none $=0 ; \geq 1$ time/d for $<1-29 \%$ of days surveyed $=1 ; \geq 1$ time/d for $30-49 \%$ of days surveyed $=2 ; \geq 1$ time $/ \mathrm{d}$ for $\geq 50 \%$ of days surveyed $=3$. The total potential score was 13 pts.

$\S$ For one child, $\geq 50 \%$ of meals was composed of staple, meat/chicken/fish/legumes and vitamin-A-rich food.

$\|$ Complete if vaccine for measles was provided to children aged $\geq 9$ months, DTP (diphtheria-pertussis-tetanus) to children aged $\geq 3$ months and BCG (tuberculosis) to children aged $<3$ months.

TMean of the group was attributed to five children because information was not available.

t+Two of six children aged 9-11 months consumed meat/chicken/fish/legumes $\geq 1$ time/d for $<50 \%$ of days surveyed, as did as eleven of sixteen children aged 12-23 months.

$\$$ Mean of the group was attributed to ten children because information was not available. 
age; (ii) 6-23 months of age; and (iii) 24-59 months of age (Table 2$)^{(23,29)}$. For children aged 6-23 months, the energy density of complementary foods was assessed from the energy content and quantity of food consumed at each meal. The mean of all meals was then estimated. Whenever the child received either staple food alone or combined with sauce or any other food, it was considered a meal. If at least $10 \mathrm{~g}$ of vitamin-A-rich foods ${ }^{(30)}$ (e.g. palm nut sauce, green leaves prepared with oil) were consumed, or $5 \mathrm{~g}$ of red palm oil, the meal was considered a source of vitamin A. The frequency of meals with vitamin-A-rich food was calculated for all children aged 6-23 months. The frequency of meals with meat/ chicken/fish/legumes was not considered for children below 9 months of age because there are no clear recommendations on their age of introduction ${ }^{(23,29)}$. For each child aged 6-23 months, the adequacy of the mean number of meals and of energy density was assessed from current recommendations for his/her breast-feeding category ${ }^{(23,29)}$. Feeding practices incorporated active feeding for children aged 0-23 months because the amount of food they consume may depend more on the caregiver's responsive feeding.

Hygiene practices included items at household and child levels. Because rainwater was collected from the roof without gutters, it was not considered as safe as that from a water pump ${ }^{(31)}$. Regarding health practices, traditional and modern treatments received the same value because their relative efficiency was unknown. If the child was not sick in either season, the maximum score was attributed. Care provided to the child's caregiver was also included in the index.

Care for women caregivers. Table 3 summarizes the indicators used to assess the seven constructs of care for women caregivers. Care was not defined for twelve women because of memory blanks regarding their last pregnancy $(n 7)$, hearing problems ( $n 2)$ or illness of the MA ( $n 3)$. Most criteria are self-explanatory and based on generally accepted recommendations. Health practices included the same components as for children with the exception of immunization and the use of a bed net; only five women did not use it in both seasons. Since no one used both types of treatment, it was not considered.

Care for the elderly. The index of care for the elderly ( $\geq 60$ years of age) includes three constructs: (i) food preparation; (ii) hygiene; and (iii) health practices (Table 4). The first two include the same indicators as for women caregivers. The type of treatment was added for health practices.

\section{Access to bealth (health services and a healthy environment)}

All households need access to appropriate health services such as those provided by a health facility located at a reasonable distance from their home, staffed with skilled personnel and stocked with appropriate medicines ${ }^{(8)}$.
Safe water and improved sanitation are also required ${ }^{(32)}$. In the Complex, only four villages have a water pump and, in another, water is trucked in by a private company. Sanitary facilities are generally limited to a simple pit latrine. About a third of villages have a health facility (11/ $35)$, although half do not have medicines or skilled personnel (6/11). The indicators used to develop an index are summarized in Table 5 and are based on accepted recommendations. No village had access to both a water pump and a functional health facility; some had neither.

\section{Access to natural resources}

Natural resources are renewable resources, i.e. soil, water, fauna and flora ${ }^{(5)}$. Our study considers fauna and flora used by the household for food and medicine. In each season, after an initial inventory in each household, its use of natural resources was measured daily during the $7 \mathrm{~d}$ period by identifying and weighing (scales: $25 \mathrm{~kg}$ accurate to $\pm 0 \cdot 1 \mathrm{~kg}$, UNICEF hanging scale, UNICEF Supply Division, Copenhagen, Denmark; $50 \mathrm{~kg}$ accurate to $\pm 0 \cdot 1 \mathrm{~kg}$, Salter, Cleveland, OH, USA; $4 \mathrm{~kg}$ accurate to $\pm 0.001 \mathrm{~kg}$, Acculab, Newton, PA, USA) each resource which entered and left the household and describing its type (mammals/reptiles/amphibians/birds, fish/shellfish, plants) and source (e.g. produced, purchased, received). The dollar value (\$US) of each resource was calculated based on local prices. The mean weekly total value of natural resources used per capita in each household, a proxy of access, was then calculated using data of both seasons.

\section{Socio-economic status}

Socio-economic status was estimated from a combination of both ownership of assets and income, over both seasons. For each of nine assets owned - (i) seeds, (ii) livestock, (iii) fishing net, (iv) snares, (v) hatchet, (vi) dugout/firearm, (vii) possession of savings in the last two months, (viii) flashlight and (ix) machete - each household initially received a value of 1 . The first seven items produced a Guttman scale with an acceptable coefficient of scalability $(0 \cdot 72)$ and reproducibility $(0 \cdot 90)$, which suggests that the underlying concept is unidimensional $^{(33)}$. Each household thus received a score of ownership of assets according to its position on the scale $^{(33)}$. Households were then grouped into tertiles. The mean weekly household income per capita was calculated with data from both seasons and households were again grouped into tertiles. For each household, a socioeconomic score was then created by adding their position on both tertiles (ownership of assets and income) for a potential maximum of 6 .

\section{Statistical analyses}

The $t$ test and one-way ANOVA were performed to assess differences in nutritional status. Pearson correlations were used to test for associations with nutritional status and its 
Table 3 Index of access to care for wives $(n 36)$ and women caregivers of children $<5$ years old ( $n$ 60): criteria and population distribution

\begin{tabular}{|c|c|c|c|c|}
\hline Constructs and indicators & Criteria & Score & $n$ & $\%$ \\
\hline \multicolumn{5}{|l|}{ Care last pregnancy/postpartum } \\
\hline \multicolumn{2}{|l|}{ Never pregnant } & 12 & 6 & 6 \\
\hline \multicolumn{2}{|l|}{ If pregnant } & & 90 & 94 \\
\hline \multirow{3}{*}{$\begin{array}{l}\text { Had help to collect wood and water during } \\
\text { last pregnancy }\end{array}$} & No & 0 & 17 & 19 \\
\hline & Yes & 2 & 69 & 77 \\
\hline & No datat & - & 4 & 4 \\
\hline \multirow{3}{*}{$\begin{array}{l}\text { Had help to collect wood and water } \\
\geq 2 \text { weeks postpartum }\end{array}$} & No & 0 & 7 & 8 \\
\hline & Yes & 2 & 74 & 82 \\
\hline & No data & - & 9 & 10 \\
\hline \multirow{3}{*}{$\begin{array}{l}\text { Received a baby/mother kit (e.g. blanket, } \\
\text { skin cream) }\end{array}$} & No & 0 & 32 & 36 \\
\hline & Yes & 1 & 51 & 57 \\
\hline & No data & - & 7 & 7 \\
\hline \multirow{4}{*}{ Number of prenatal visits } & 0 & 0 & 24 & 27 \\
\hline & $1-3$ & 1 & 36 & 40 \\
\hline & $\geq 4$ & 2 & 27 & 30 \\
\hline & No data & - & 3 & 3 \\
\hline \multirow[t]{4}{*}{ Number of tetanus shots } & 0 & 0 & 29 & 32 \\
\hline & 1 & 1 & 6 & 7 \\
\hline & $\geq 2$ & 2 & 51 & 57 \\
\hline & No data & - & 4 & 4 \\
\hline \multirow{3}{*}{ Ever used Fe tablets } & No & 0 & 63 & 70 \\
\hline & Yes & 1 & 24 & 27 \\
\hline & No data & - & 3 & 3 \\
\hline \multirow{3}{*}{ Used traditional medicine during pregnancy } & No & 0 & 49 & 54 \\
\hline & Yes & 1 & 37 & 41 \\
\hline & No data & - & 4 & 4 \\
\hline \multirow[t]{3}{*}{ Site of, and help at, delivery } & Home, untrained $\ddagger$ & 0 & 53 & 59 \\
\hline & Health facility, trained help & 1 & 32 & 36 \\
\hline & No data & - & 5 & 5 \\
\hline \multicolumn{2}{|l|}{ Total } & $\begin{array}{l}12 \text { points (pts) } \\
\text { standardized (std) to } 5 \text { pts }\end{array}$ & 96 & 100 \\
\hline \multicolumn{5}{|l|}{ Reproductive health } \\
\hline Never pregnant & & 4 & 6 & 7 \\
\hline If pregnant & & & 90 & 93 \\
\hline Age at first pregnancy (years) & $<19$ & 0 & 72 & 80 \\
\hline & $\geq 19$ & 1 & 14 & 16 \\
\hline & No data & - & 4 & 4 \\
\hline Interval between last two pregnancies & $\leq 12$ & -0.5 & 10 & 11 \\
\hline (months) & $12-23$ & 0 & 24 & 27 \\
\hline & $\geq 24$ & 1 & 40 & 44 \\
\hline & No data & - & 16 & 18 \\
\hline Ever used contraception & No & 0 & 83 & 87 \\
\hline & Yes & 1 & 10 & 10 \\
\hline & No data & - & 3 & 3 \\
\hline Proportion of live births & $<50 \%$ & -1 & 14 & 16 \\
\hline & $50-74 \%$ & -0.5 & 22 & 24 \\
\hline & $75-99 \%$ & 0 & 22 & 24 \\
\hline & $100 \%$ & 1 & 29 & 32 \\
\hline & No data & - & 3 & 3 \\
\hline Total & & 4 pts (std to 5 pts) & 96 & 100 \\
\hline Autonomy & & & & \\
\hline Control over household income & None & 0 & 49 & 51 \\
\hline & Partial & 1 & 9 & 9 \\
\hline & Full & 3 & 38 & 40 \\
\hline Participation in decision making for & No & 0 & 20 & 21 \\
\hline food purchase & Yes & 1 & 76 & 79 \\
\hline Total & & 4 pts (std to 5 pts) & 96 & 100 \\
\hline Workload & & & & \\
\hline$\%$ of time over two weeks & & & & \\
\hline She provides wood & $\geq 75 \%$ & 0 & 28 & 29 \\
\hline & $50-74 \%$ & 1 & 21 & 22 \\
\hline & $25-49 \%$ & 2 & 12 & 13 \\
\hline & $<25 \%$ & 3 & 35 & 36 \\
\hline She provides water & $\geq 75 \%$ & 0 & 25 & 26 \\
\hline & $50-74 \%$ & 1 & 19 & 20 \\
\hline & $25-49 \%$ & 2 & 23 & 24 \\
\hline & $<25 \%$ & 3 & 29 & 30 \\
\hline
\end{tabular}


Table 3 Continued

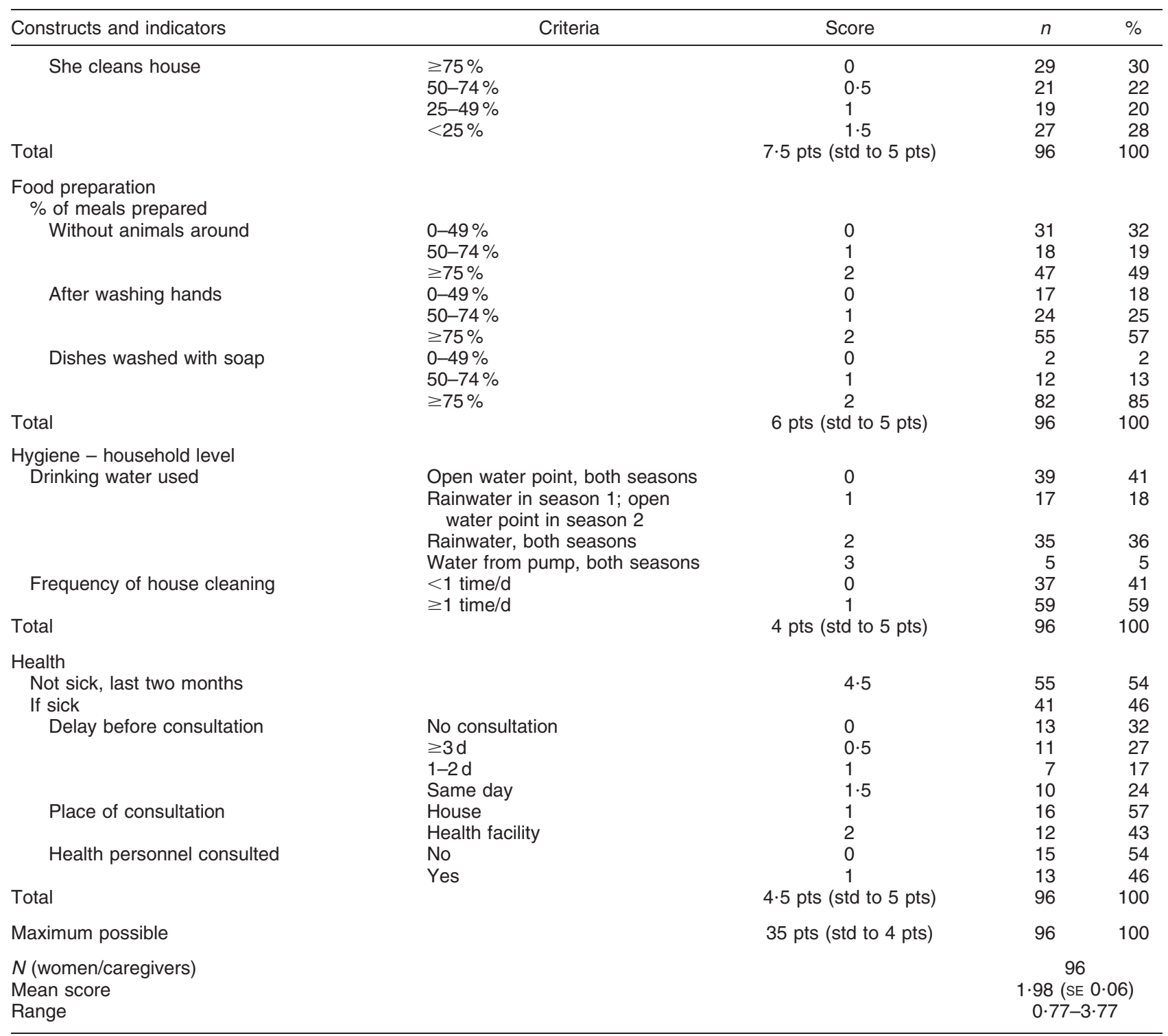

tMean value of the group was assigned to women with no data. ‡One woman gave birth without any help.

determinants. Stepwise multiple linear regressions were performed to predict nutritional status (actual $Z$-score or BMI). The first model included its postulated determinants at the immediate level (individual health status and nutrient adequacy) and underlying level (household access to food, health and natural resources, and individual access to care). Individual-level mediators such as age of women were added in the second model. The third model integrated household-level mediators such as schooling of the household head. The last model included the community location (also a proxy for the ethnic group). The different models were run separately. The eigenvalues, condition index and proportion of variances were checked to detect collinearity in the final model. A probability value of 0.05 was accepted as statistically significant, although our final model considered variables significant at $P<0 \cdot 08$.

\section{Results}

As previously described, about $35 \%$ of children aged 0-23 months and 60\% of those aged 24-59 months were stunted ( $Z$-score below -1), while $29 \%$ and $18 \%$ respectively were wasted. About $26 \%$ of the elderly and $9 \%$ of adults were underweight ${ }^{(6)}$. Nutritional status did not vary with sociodemographic characteristics except for the following: children aged 0-23 months and 24-59 months were generally better off if they lived in a household where the head had attended school for more than 
Table 4 Index of access to care for the elderly: criteria and population distribution

\begin{tabular}{|c|c|c|c|c|}
\hline Constructs and indicators & Criteria & Score & $n$ & $\%$ \\
\hline \multicolumn{5}{|l|}{ Food preparation } \\
\hline \multirow[t]{3}{*}{ Without animals around } & $0-49 \%$ & 0 & 40 & 40 \\
\hline & $50-74 \%$ & 1 & 17 & 17 \\
\hline & $\geq 75 \%$ & 2 & 44 & 43 \\
\hline \multirow[t]{3}{*}{ After washing hands } & $0-49 \%$ & 0 & 15 & 15 \\
\hline & $50-74 \%$ & 1 & 20 & 20 \\
\hline & $\geq 75 \%$ & 2 & 66 & 65 \\
\hline \multirow[t]{3}{*}{ Dishes washed with soap } & $0-49 \%$ & 0 & 3 & 3 \\
\hline & $50-74 \%$ & 1 & 9 & 9 \\
\hline & $\geq 75 \%$ & 2 & 89 & 88 \\
\hline \multicolumn{2}{|l|}{ Total } & $\begin{array}{l}6 \text { points (pts) } \\
\text { standardized (std) to } 5 \text { pts }\end{array}$ & 101 & 100 \\
\hline \multicolumn{5}{|l|}{ Hygiene - household level } \\
\hline \multirow[t]{4}{*}{ Drinking water used } & Open water point, both seasons & 0 & 31 & 31 \\
\hline & $\begin{array}{l}\text { Rainwater in season 1; open } \\
\text { water point in season } 2\end{array}$ & 1 & 34 & 34 \\
\hline & Rainwater, both seasons & 2 & 31 & 31 \\
\hline & Water from pump, both seasons & 3 & 5 & 5 \\
\hline \multirow[t]{2}{*}{ Frequency of house cleaning } & $<1$ time $/ \mathrm{d}$ & 0 & 45 & 45 \\
\hline & $\geq 1$ time $/ \mathrm{d}$ & 1 & 56 & 55 \\
\hline Total & & 4 pts (std to 5 pts) & 101 & 100 \\
\hline \multicolumn{5}{|l|}{ Health } \\
\hline \multicolumn{2}{|l|}{ Not sick, last two months } & $6 \cdot 5$ & 54 & 53 \\
\hline If sick & & & 47 & 47 \\
\hline \multirow[t]{4}{*}{ Delay before consultation } & No consultation & 0 & 6 & 13 \\
\hline & $\geq 3 d$ & 0.5 & 0 & 0 \\
\hline & $1-2 d$ & 1 & 31 & 66 \\
\hline & Same day & 1.5 & 10 & 21 \\
\hline \multirow[t]{2}{*}{ Place of consultation } & House & 1 & 24 & 59 \\
\hline & Health facility & 2 & 17 & 41 \\
\hline \multirow[t]{2}{*}{ Type of treatmentt } & Traditional/modern & 1 & 35 & 90 \\
\hline & Both & 2 & 4 & 10 \\
\hline \multirow[t]{2}{*}{ Health personnel consulted } & No & 0 & 22 & 54 \\
\hline & Yes & 1 & 19 & 46 \\
\hline Total & & $6.5 \mathrm{pts}$ (std to $5 \mathrm{pts}$ ) & 101 & 100 \\
\hline Maximum possible & & 15 pts (std to 4 pts) & 101 & 100 \\
\hline$N$ (elderly) & & & & \\
\hline Mean score & & & $2 \cdot 58$ & \\
\hline Range & & & $1 \cdot 3$ & \\
\hline
\end{tabular}

†Two individuals were not treated although they consulted with health personnel.

3 years, while young women (aged $\leq 20$ years) had a lower BMI than those aged $21-39$ years or even $\geq 40$ years (Table 6). Most households (80\%) were food-insecure: $16 \%$ severely and $23 \%$ moderately (Table 1 ). Access to care was far from adequate and it appeared lower for women than for children or the elderly (Tables 2-4). Access to health showed a fairly broad range (Table 5 ).

Among children aged 0-23 months, positive correlations were observed between length-for-age and access to care and health but not to food (Table 7). In children aged 24-59 months, weight-for-height was positively correlated with health status. Among women, BMI was negatively correlated with access to food and positively associated with care (Table 8). In children aged 24-59 months and the elderly, there was no significant correlation between nutritional status and access to food, care or health, although access to food and care were positively correlated in children aged 24-59 months, while the opposite was true for women.

Household access to natural resources was generally not associated with nutritional status (Tables 7 and 8), although it was associated with weight-for-height in children aged 24-59 months. With the exception of the latter group, it was however associated with access to food. In children aged 0-23 months, it was negatively correlated with health status and with access to health. Among children aged 24-59 months, it was positively associated with health status and with access to care. Among women caregivers, access to natural resources was negatively correlated with access to health.

No association was observed between nutrient adequacy and access food, care, health or natural resources, except in the elderly where it was positively correlated with access to food. Neither was health status associated 
Table 5 Index of household access to health services and a healthy environment: criteria and population distribution

\begin{tabular}{|c|c|c|c|c|c|}
\hline Level & Items & Criteria & Score & $n$ & $\%$ \\
\hline Community + & $\begin{array}{l}\text { Water pump or } \\
\text { Health facility with trained health personnel } \\
\text { and basic drugsł }\end{array}$ & $\begin{array}{l}\text { None } \\
\text { Yes to } \geq 1\end{array}$ & $\begin{array}{l}0 \\
1\end{array}$ & $\begin{array}{l}68 \\
27\end{array}$ & $\begin{array}{l}72 \\
28\end{array}$ \\
\hline Household & $\begin{array}{l}\text { Latrine: distance from house in metres } \\
\text { Garbage pit: distance from house in metres }\end{array}$ & $\begin{array}{l}\text { None } \\
<20 \\
\geq 20 \\
<10 \\
10-19 \\
\geq 20\end{array}$ & $\begin{array}{l}0 \\
1 \\
2 \\
0 \\
1 \\
2\end{array}$ & $\begin{array}{r}11 \\
37 \\
47 \\
8 \\
31 \\
56\end{array}$ & $\begin{array}{r}12 \\
39 \\
49 \\
8 \\
33 \\
59\end{array}$ \\
\hline Maximum & & & $\begin{array}{c}5 \text { points (pts) } \\
\text { standardized to } 4 \text { pts }\end{array}$ & 95 & 100 \\
\hline $\begin{array}{l}N \text { (households) } \\
\text { Mean score } \\
\text { Range }\end{array}$ & & & & \multicolumn{2}{|c|}{$\begin{array}{c}95 \\
2 \cdot 75(\text { SE } 0 \cdot 10) \\
0 \cdot 80-4.00\end{array}$} \\
\hline
\end{tabular}

tOnly Mourindi had a water pump while Doussala was the only community with a functional health centre.

‡Drugs were iodine, chloroquine/aspirin, oral rehydration salts and eye ointment.

with access to care, health or food in any group except for women caregivers, where it was negatively associated with access to food: the most food-secure households included women with the poorest health status and the poorest nutritional status.

In the final model of regression analysis for children aged 0-23 months, access to care and health explained $7 \cdot 2 \%$ and $11 \cdot 2 \%$ of the variance in length-for-age (Table 9). Together, they explained $18.4 \%$ of its variance. In the case of weightfor-length, access to health explained $9 \cdot 3 \%$ of its variance, while living in a household where the head attended school for more than 3 years and with a high dependency ratio each explained another $9 \cdot 4 \%$ and $13 \cdot 2 \%$. However, when we controlled for the village of Doussala, the only village with a health centre, none of the determinants remained significant. Among children aged 24-59 months, health status was the best predictor of weight-for-height and it explained $15 \cdot 2 \%$ of its variance. None of the potential determinants predicted height-for-age.

For women, living in a more food-secure household was associated with a poorer nutritional status as was being younger than 20 years (although the latter showed collinearity; Table 9). Together, they predicted $17 \cdot 8 \%$ of the variance in BMI. Among the elderly, none of the underlying determinants predicted nutritional status. However, nutrient adequacy predicted $6 \cdot 2 \%$ of the variance associated with BMI. For each group, results were unchanged when the regression analysis considered only individuals with no missing data.

\section{Discussion}

While the per capita use of natural resources by the household was generally not associated with the nutritional status of individuals from vulnerable groups and did not predict it, it was usually associated with household food security. However, neither was household food security a predictor of nutritional status. Living in more food-secure households or living in households that use more natural resources - as assessed by its value per capita - does not equate with better nutritional status of vulnerable groups. In fact, the opposite was apparent in women. By practising agriculture and gathering resources, women were likely making an important contribution to household food security but it seemed to be at the expense of their own well-being. The more natural resources their household used, the more food-secure it was; but the more their household was food-secure, the worst was their nutritional status. The situation appears worst if women were young.

Measuring food security at the household level in valid and reliable ways remains a challenge ${ }^{(17)}$. It would have been better to use an indicator which respected all validation criteria ${ }^{(34)}$ but, at the time of the survey, no such measure existed for our context. We therefore integrated in a single measure indicators of the major dimensions of food security in an attempt to have an overview of the situation.

However, our measures of both food security and use of natural resources were household-level measures. They reflect the potential intra-household allocation of either food or natural resources. It may not correspond to the individual situation of household members. This may account for their lack of an association with individual nutritional status. For example, we have previously shown that adult and adolescent males had a better score of global nutrient adequacy than their female counterparts ${ }^{(6)}$. In a household, as in society, food and perhaps natural resources are not necessarily allocated according to biological requirements. This raises the question as to how resources (including food) are allocated among individuals in the household and how the individual's access to food and other resources is associated with their nutritional status, particularly for women and adolescent girls. 


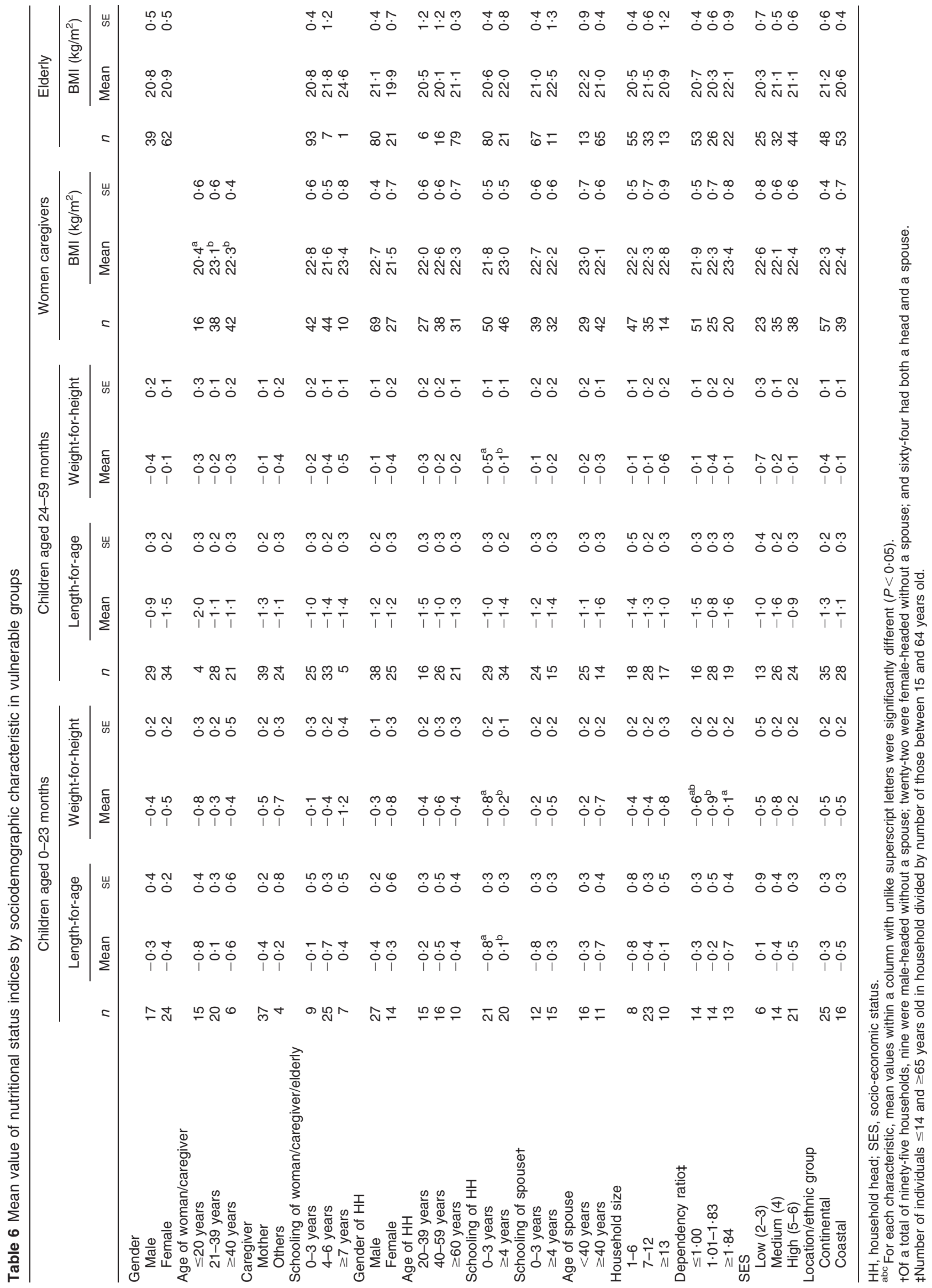


Table 7 Correlation matrices (Pearson's $r$ ) for children aged 0-23 months and 24-59 months: nutritional status and its determinants

\begin{tabular}{|c|c|c|c|c|c|c|c|c|}
\hline & \multicolumn{2}{|c|}{ Nutritional status } & \multicolumn{2}{|c|}{ Immediate determinants } & \multicolumn{3}{|c|}{$\begin{array}{l}\text { Underlying determinants } \\
\text { (access to) }\end{array}$} & \multirow[b]{2}{*}{$\begin{array}{c}\text { Access to } \\
\text { natural resources }\end{array}$} \\
\hline & $\begin{array}{l}\text { Length/height- } \\
\text { for-age }\end{array}$ & $\begin{array}{l}\text { Weight-for- } \\
\text { length/height }\end{array}$ & $\begin{array}{l}\text { Nutrient } \\
\text { adequacy }\end{array}$ & $\begin{array}{l}\text { Health } \\
\text { status }\end{array}$ & Food & Care & Health & \\
\hline \multicolumn{9}{|c|}{ Children aged $0-23$ months ( $n$ 41) } \\
\hline Nutritional status & 1 & 1 & & & & & & \\
\hline \multicolumn{9}{|l|}{ Immediate } \\
\hline Nutrient adequacy & 0.256 & 0.065 & 1 & & & & & \\
\hline Health status & $-0 \cdot 120$ & -0.099 & 0.030 & 1 & & & & \\
\hline \multicolumn{9}{|l|}{ Underlying (access to) } \\
\hline Food & $-0 \cdot 103$ & -0.085 & $-0 \cdot 060$ & $-0 \cdot 152$ & 1 & & & \\
\hline Care & $0 \cdot 330^{*}$ & 0.086 & -0.065 & 0.088 & $0 \cdot 283$ & 1 & & \\
\hline Health & $0.335^{\star}$ & -0.281 & $0 \cdot 270$ & -0.029 & -0.119 & $0 \cdot 202$ & 1 & \\
\hline $\begin{array}{l}\text { Access to natural } \\
\text { resources }\end{array}$ & -0.096 & $0 \cdot 281$ & -0.260 & $-0 \cdot 435^{\star *}$ & $0 \cdot 322^{*}$ & 0.046 & $-0 \cdot 346^{*}$ & 1 \\
\hline \multicolumn{9}{|c|}{ Children aged $24-59$ months ( $n$ 63) } \\
\hline Nutritional status & 1 & 1 & & & & & & \\
\hline \multicolumn{9}{|l|}{ Immediate } \\
\hline Nutrient adequacy & 0.029 & $0 \cdot 183$ & 1 & & & & & \\
\hline Health status & -0.015 & $0 \cdot 390^{* *}$ & $0 \cdot 220$ & 1 & & & & \\
\hline \multicolumn{9}{|l|}{ Underlying (access to) } \\
\hline Food & -0.039 & -0.036 & $0 \cdot 117$ & 0.085 & 1 & & & \\
\hline Care & 0.006 & $0 \cdot 102$ & 0.089 & $0 \cdot 199$ & $0.456^{\star \star}$ & 1 & & \\
\hline Health & $-0 \cdot 159$ & $-0 \cdot 149$ & 0.063 & -0.038 & $0 \cdot 178$ & $0 \cdot 178$ & 1 & \\
\hline $\begin{array}{l}\text { Access to natural } \\
\text { resources }\end{array}$ & -0.029 & $0 \cdot 268^{*}$ & 0.089 & $0 \cdot 388^{\star *}$ & $0 \cdot 117$ & $0 \cdot 280^{*}$ & $-0 \cdot 190$ & 1 \\
\hline
\end{tabular}

Correlation was statistically significant: ${ }^{*} P<0 \cdot 05,{ }^{* \star} P<0 \cdot 01$.

Table 8 Correlation matrices (Pearson's $r$ ) for women caregivers and the elderly: nutritional status and its determinants

\begin{tabular}{|c|c|c|c|c|c|c|c|}
\hline & \multirow[b]{2}{*}{$\begin{array}{l}\text { Nutritional } \\
\text { status }\end{array}$} & \multicolumn{2}{|c|}{ Immediate determinants } & \multicolumn{3}{|c|}{ Underlying determinants (access to) } & \multirow[b]{2}{*}{$\begin{array}{l}\text { Access to natura } \\
\text { resources }\end{array}$} \\
\hline & & $\begin{array}{l}\text { Nutrient } \\
\text { adequacy }\end{array}$ & $\begin{array}{l}\text { Health } \\
\text { status }\end{array}$ & Food & Care & Health & \\
\hline & & & & \multicolumn{3}{|c|}{ Women ( $n$ 96) } & \\
\hline Nutrient adequacy & -0.042 & 1 & & & & & \\
\hline Health status & 0.048 & 0.040 & 1 & & & & \\
\hline \multicolumn{8}{|l|}{ Underlying (access to) } \\
\hline Food & $-0.354^{\star *}$ & $0 \cdot 162$ & $-0 \cdot 207^{\star}$ & 1 & & & \\
\hline Care & $0 \cdot 205^{\star}$ & $-0 \cdot 111$ & 0.042 & $-0.253^{*}$ & 1 & & \\
\hline Health & $0 \cdot 112$ & $0 \cdot 178$ & $0 \cdot 177$ & -0.044 & $0 \cdot 112$ & 1 & \\
\hline \multirow[t]{2}{*}{ Access to natural resources } & -0.064 & -0.035 & $-0 \cdot 177$ & $0 \cdot 202^{*}$ & $0 \cdot 010$ & $-0 \cdot 232^{*}$ & 1 \\
\hline & & & & \multicolumn{3}{|c|}{ Elderly ( $n$ 101) } & \\
\hline Nutritional status & 1 & & & & & & \\
\hline \multicolumn{8}{|l|}{ Immediate } \\
\hline Nutrient adequacy & $0 \cdot 249^{*}$ & 1 & & & & & \\
\hline Health status & 0.002 & 0.056 & 1 & & & & \\
\hline \multicolumn{8}{|l|}{ Underlying (access to) } \\
\hline Food & -0.023 & $0.428^{\star \star}$ & -0.184 & 1 & & & \\
\hline Care & $0 \cdot 117$ & 0.059 & 0.067 & $0 \cdot 112$ & 1 & & \\
\hline Health & $-0 \cdot 060$ & $-0 \cdot 113$ & $0 \cdot 154$ & -0.049 & 0.065 & 1 & \\
\hline Access to natural resources & -0.097 & -0.096 & -0.017 & $0 \cdot 450^{\star *}$ & -0.033 & -0.086 & 1 \\
\hline
\end{tabular}

Correlation was statistically significant: ${ }^{*} P<0.05,{ }^{* *} P<0.01$.

Among young children, the absence of a relationship between access to food and nutritional status has been observed before and was explained by the relative importance of care ${ }^{(25)}$. This is also what we observe. Children aged 0-23 months who received better care had a better nutritional outcome. Because of the high velocity of growth in the first two years ${ }^{(35)}$, because young children are less capable of communicating their needs and because they actually need a relatively small amount of food, children at this age might be more vulnerable to poor care practices than to household food insecurity.

As to the absence of a relationship between care and height-for-age in children aged 24-59 months, this might 
Table 9 Regression of nutritional status on its determinants: final models in each group

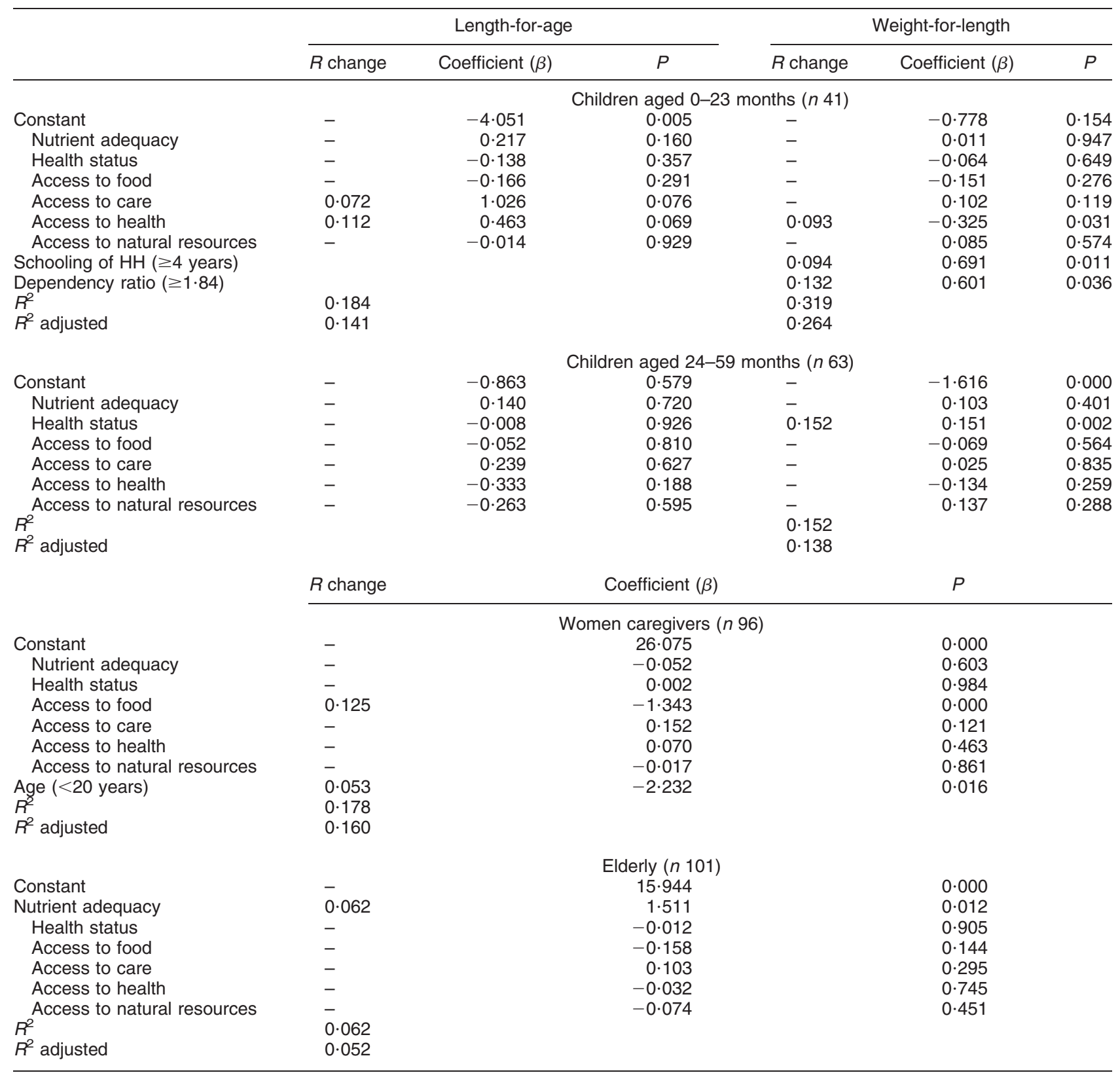

be attributed to the fact that stunting after 2-3 years of age is nearly irreversible ${ }^{(36,37)}$. Thus, the impact of care, or any other determinant, on their height-for-age might be less noticeable.

To assess care, we defined composite indices that combined various practices on several constructs because its impact on nutritional status is the outcome of a large set of practices which can cluster and because some can be beneficial while others less, depending on the availability of resources to the caregiver or to the household $^{(38)}$. It has also been suggested that a minimum number of good practices may be necessary to obtain health benefits. Furthermore, to reduce biases and to increase the reliability of data, we collected data over several days, we used continuous monitoring observations which are considered as the gold standard ${ }^{(38)}$ and we had sought to establish a good rapport with the participants $^{(38)}$.

As for the elderly, the small number of items used to assess care may not have captured their reality. This, added to the inability of our measure to assess the individual's access to food or to resources and the probable modification of their food intake because of the survey ${ }^{(6)}$, could account for our results.

With the exception of children aged 0-23 months, access to health services and a healthy environment was not associated with nutritional status, probably because individuals in other groups were less frequently ill and/or 
because of the generally poor quality of the services and the possible weakness of our measure. However, a better health status could help to reduce wasting in 24-59month-old children.

Finally, given the expected synergy between health status and dietary adequacy, it is to be expected that the impact of the underlying determinants would manifest themselves more directly on nutritional status. The synergy between access food, to care and to health remains to be estimated but could account for much of the remaining effect on nutritional status.

To our knowledge, this is the first time that the same study has assessed not only the impact of access to food, to care and to health to examine their relationship with nutritional status, but also care for children, as well as for women and the elderly. In developing countries, previous studies mainly focused on young children and investigated the link between nutritional status and sets of care practices ${ }^{(26,39)}$. The relationship between nutritional status and household access to natural resources has also never been investigated before.

\section{Conclusion}

Our results reiterate the importance of improving care practices for children aged 0-23 months, as well as their access to health services and a healthy environment, in populations where nutrition is of concern, so as to reverse the process of undernutrition and to help children achieve better growth and development. This could also improve the situation of children aged 24-59 months. In women, more attention should be given to investigating their role in household food security to ensure that their contribution is not at the expense of their own care, first for their own well-being but also for their important role in child nutrition and caring for others. This includes reaching a better understanding of the intra-household allocation of food and of other resources, an understanding which could also benefit the elderly and perhaps other groups. The current household measures of food security and use of natural resources could mask the true relationship between the access of individuals to both food and natural resources and their nutritional status. They need to be complemented by measures of individual food security and individual use of natural resources. Finally, although there are promising measures, such as composite indices, that can be or are being used to assess the degree of fulfilment of the underlying determinants, more research is required to develop and validate them. A better measure of care practices towards the elderly is particularly needed.

The new nutrition science project points to the importance of now combining the environmental, social and biological dimensions of nutrition in order to fulfil its potential to preserve, maintain, develop and sustain life on
Earth given the context of the 21st century ${ }^{(40)}$. A better knowledge of how people relate to their environment is likely one of the steps needed to achieve such a goal, as well as to help achieve the Millennium Development Goals.

\section{Acknowledgements}

We are particularly grateful to the participants of the survey, to the nutrition survey team and to the Ministry of Water and Forests. The financial support of the MacArthur Foundation (Grant no. 98-551194-GSS), the Directorate General for International Cooperation (DGIS) and the World Wide Fund for Nature (WWF) is acknowledged. The main author was employed by the WWF while planning and carrying out the survey, although data analysis and interpretation were done subsequently and are entirely the responsibility of the authors. For the main author, this was part of the requirements for obtaining her $\mathrm{PhD}$ at Laval University with the participation of her supervisors, the second and third authors. There is no conflict of interest.

\section{References}

1. United Nations Development Programme (2003) Millennium Development Goals: A Compact Among Nations to End Human Poverty. Human Development Report 2003. Oxford: Oxford University Press.

2. Pimentel D, McNair M, Buck L, Pimentel M \& Kamil J (1997) The value of forests to world food security. Hum Ecol 25, 91-120.

3. Roe D \& Hollands M (2003) Protected Areas: How Much is Enough? London: International Institute for Environment and Development.

4. Ministère de la Planification de l'Environnement et de l'Aménagement du Territoire (1993) Recensement général de la population et de l'habitat de 1993: résultats détaillés. Libreville, Gabon: MPEAT.

5. Ministère des Eaux et Forêts des Postes des Télécommunications et de l'Environnement (1996) Textes juridiques sur la protection des forêts, de l'environnement et de la faune au Gabon. Libreville, Gabon: Projet Forêts et Environnement/Ambassade du Canada.

6. Blaney S, Beaudry M, Latham M \& Thibault M (2007) Nutritional status and dietary adequacy in rural communities of a protected area in Gabon. Public Health Nutr (Submitted).

7. UNICEF (1990) Strategy for Improved Nutrition of Children and Women in Developing Countries. New York: UNICEF.

8. Administrative Committee on Coordination/Sub-Committee on Nutrition (1991) Some Options for Improving Nutrition in the 90s. Geneva: ACC/SCN.

9. Pekkarinen M (1970) Methodology in the collection of food consumption data. World Rev Nutr Diet 12, $145-171$.

10. World Health Organization (1995) Physical Status: The Use and Interpretation of Anthropometry. WHO Technical Report Series no. 854. Geneva: WHO.

11. Grantham-McGregor S, Cheung YB, Cueto S, Glewwe P, Richter L \& Strupp B; International Child Development Steering Group (2007) Developmental potential in the first 5 years for children in developing countries. Lancet 369, $60-70$. 
12. WHO Multicentre Growth Reference Study Group (2006) WHO Child Growth Standards based on length/height, weight and age. Acta Paediatr Suppl 450, 76-85.

13. Metropolitan Life Insurance Company (1999) 1979 Build Study. Chicago, IL: Society of Actuaries and Associations of Life Insurance Medical Directors of America.

14. Food Agriculture Organization of the United Nations (1996) Rome Declaration on World Food Security and World Food Summit Plan of Action. Rome: FAO.

15. Maxwell S \& Smith M (1992) Household food security: a conceptual review. In Household Food Security: Concepts, Indicators, Measurements - A Technical Review, pp. 1-72 [S Maxwell and TR Frankenberger, editors]. New York/Rome: UNICEF/International Fund for Agricultural Development.

16. Sen AK (1981) Poverty and Famines: An Essay on Entitlement and Deprivation. Oxford: Clarendon Press.

17. Maxwell D, Levin C, Armar-Klemesu M, Ruel M, Morris S \& Ahiadeke C (2000) Urban Livelihood and Food and Nutrition Security in Greater Accra, Ghana. Research Report no. 112. Washington, DC: International Food Policy Research Institute.

18. Jonsson U \& Toole D (1991) Conceptual Analysis of Resources and Resource Control in Relation to Malnutrition, Disease and Mortality. New York: UNICEF.

19. Blaney S, Mbouity S, Moussounda Nzamba P, Nkombé J-M \& Thibault M (1998) Caractéristiques socio-économiques des populations du département de la Douigny et de Louango. Libreville, Gabon: WWF-Programme Régional pour l'Afrique Centrale.

20. Blaney S, Mbouity S, Nkombé J-M \& Thibault M (1997) Caractéristiques socio-économiques des populations des départements de Ndougou et de la Basse-Banio. Libreville, Gabon: WWF-Programme Régional pour l'Afrique Centrale.

21. Frongillo EA \& Nanama S (2006) Development and validation of an experience-based measure of household food insecurity within and across seasons in Northern Burkina Faso. J Nutr 136, Suppl., S1409-S1419.

22. International Conference on Nutrition (1992) Plan of Action for Nutrition. Rome: FAO/WHO.

23. Brown K, Dewey KG \& Allen LH (1998) Complementary Feeding of Young Children in Developing Countries: A Review of Current Scientific Knowledge. WHO/NUT/98.1. Geneva: Program of Nutrition, Department of Family and Reproductive Health, WHO.

24. Engle P, Lhotska L \& Armstrong H (1997) The Care Initiative: Assessment, Analysis and Action to Improve Care for Nutrition. New York: UNICEF.

25. Pelletier D, Deneke K, Kidane Y, Haile B \& Negussie F (1995) The food-first bias and nutrition policy: lessons from Ethiopia. Food Policy 20, 279-298.

26. Ruel M \& Menon P (2002) Child feeding practices are associated with child nutritional status in Latin America: innovative uses of the Demographic and Health Surveys. J Nutr 132, 1180-1187.
27. Direction Générale de la Statistique et des Etudes Economiques \& ORC Macro (2001) Enquête démographique et de santé Gabon 2000. Libreville, Gabon/Calverton, MD: DGSEE/Fonds des Nations unies pour la population/ORC Macro.

28. Arimond M \& Ruel M (2002) Progress in Developing an Infant and Child Feeding Index: An Example using the Ethiopia Demographic and Health Survey 2000. Food Consumption and Nutrition Division Discussion Paper no. 143. Washington, DC: International Food Policy Research Institute.

29. Dewey K \& Brown K (2003) Update on technical issues concerning complementary feeding of young children in developing countries and implications for intervention programs. Food Nutr Bull 24, 5-28.

30. Helen Keller International (1993) How to use the HKI Food Frequency Method to Assess Community Risk of Vitamin A Deficiency. New York: HKI - Vitamin A Technical Assistance Program.

31. UNICEF (2000) Global Water Supply and Sanitation Assessment 2000 Report. New York: UNICEF.

32. Esrey SA, Andersson I, Hillers A \& Sawyer R (2001) Closing the Loop: Ecological Sanitation for Food Security. Mexico: United Nations Development Programme/Swedish International Development Agency.

33. Guttman L (1950) The basis for scalogram analysis. In Measurement and Prediction Studies in Social Psychology in World War II, pp. 60-90 [SA Stouffer, L Guttman, EA Suchman, PF Lazardsfeld, SA Star and JA Clausen, editors]. Princeton, NJ: Princeton University Press.

34. Frongillo EA Jr (1999) Validation of measures of food insecurity and hunger. J Nutr 129, Suppl., S506-S509.

35. Martorell R (1995) Promoting healthy growth: rationale and benefits. In Child Growth and Nutrition in Developing Countries: Priorities for Action, pp. 15-31 [P PinstrupAndersen, D Pelletier and H Alderman, editors]. Ithaca, NY: Cornell University Press.

36. Martorell R, Riviera J, Kaplowits H \& Pollitt E (1992) Long term consequences of growth retardation during early childhood. In Human Growth: Basic and Clinical Aspects, pp. 143-149 [M Hernandez and J Argente, editors]. Amsterdam: Elsevier.

37. Administrative Committee on Coordination/Sub-Committee on Nutrition (1997) The Third Report on the World Nutrition Situation. Geneva: ACC/SCN.

38. Ruel MT \& Arimond M (2003) Measuring Childcare Practices: Approaches, Indicators, and Implications for Programs. Food Policy Review no. 6. Washington, DC: International Food Policy Research Institute.

39. Sawadogo P, Martin-Prével Y, Savy M, Kameli Y, Traissac P, Traoré AS \& Delpeuch F (2006) An infant and child feeding index is associated with the nutritional status of 6 to 23 month old children in rural Burkina Faso. J Nutr 136, Suppl., S656-S663.

40. Cannon G \& Leitzmann C (2005) The new nutrition science project. Public Health Nutr 8, 673-694. 